\title{
SEXUALITY AND EVIL: LADY MACBETH IN THE INDIAN FILM ADAPTATIONS OF MACBETH MAQBOOL AND VEERAM*
}

\author{
Rosa García-Periago \\ Universidad de Murcia
}

\begin{abstract}
An early Indian film adaptation of Macbeth, Jwala (dir. Vinayak, 1938) shows a Lady Macbeth that sides with Banquo against Macbeth, as if an evil female character were difficult to conceive in the Indian imagination. In 21st century film adaptations of Macbeth, Maqbool (dir. Vishal Bhardwaj, 2003) and Veeram (dir. Jayaraj, 2017), the female character is as evil as in the source text. Yet, neither Nimmi (Lady Macbeth in Maqbool) nor Kuttimani (Lady Macbeth in Veeram) is married to Macbeth at the outset of the film, the implication being an Indian married woman is incapable of such atrocities. In both movies, sexual drive becomes crucial in the course of events. By analyzing the role of Lady Macbeth in Maqbool and Veeram, this paper aims to show that these Lady Macbeths are as based on the play as on the role of the vamp (the evil woman) in popular Indian movies, since characters that are sexually driven are always condemned to death.
\end{abstract}

Keywords: Lady Macbeth, Indian Cinema, Sexuality, Evil, Maqbool, Veeram.

\author{
SEXUALIDAD Y MALDAD: LADY MACBETH EN LAS ADAPTACIONES \\ CINEMATOGRÁFICAS INDIAS DE MACBETH MAQBOOL \\ Y VEERAM
}

\section{RESUMEN}

Una adaptación india de Macbeth llamada Jwala (dir. Vinayak, 1938) muestra una Lady Macbeth que se une a Banquo en contra de Macbeth, como si un personaje femenino malo fuera difícil de concebir en la India. En las adaptaciones cinematográficas indias de Macbeth del siglo xxi, Maqbool (dir. Vishal Bhardwaj, 2003) y Veeram (dir. Jayaraj, 2017), Lady Macbeth es tan cruel como en la obra original. Sin embargo, ni Nimmi (Lady Macbeth en Maqbool) ni Kuttimani (Lady Macbeth en Veeram) están casadas con Macbeth al principio de la película, con la implicación de que una mujer india casada es incapaz de cometer esas barbaridades. En las dos películas, el deseo sexual contribuye de forma significativa en el desarrollo de los hechos. Al analizar el papel de Lady Macbeth en Maqbool y Veeram, este artículo pretende mostrar cómo estas Lady Macbeths están tan basadas en la obra como en el papel de la femme fatale del cine popular indio, ya que los personajes que tienen apetito sexual tienen un final trágico.

Palabras Clave: Lady Macbeth, cine indio, sexualidad, crueldad, Maqbool, Veeram.

DOI: https://doi.org/10.25145/j.recaesin.2021.83.08

Revista Canaria de Estudios Ingleses, 83; November 2021, pp. 105-115; ISSN: e-2530-8335 
Lokendra Arambam's The Stage of Blood (an Indian adaptation of Macbeth for the stage, 1997) includes a Lady Macbeth that is the protagonist's "alter ego/ conscience and is played by the same actor" (Trivedi 2005: 51). In an early Indian film adaptation of Macbeth, Jwala (dir. Vinayak, 1938), Lady Macbeth is not just the conscience, but even sides with Banquo against Macbeth, showing a major (and transgressive) reworking of the Shakespearean source, displaying her moral superiority, as if an evil female character was difficult to conceive in the Indian imagination. As Poonam Trivedi notes (2007: 148), the film Agneepath (dir. Mukul Anand, 1990) echoes Macbeth when the mother of the protagonist and mafia don Vijay Chavan (starring the well-known Amitabh Bachchan) states: "all the water of Bombay will not cleanse your hands" (01:09:28). The line alludes to act 5, scene 1 from the play when Lady Macbeth, completely undone by guilt and having lost her mind, sleepwalks through Macbeth's castle seeing blood on her hands and trying to clean it. ${ }^{1}$ Yet, in Agneepath, the quotation and its implications differ from the source text. It does not refer to a woman trying to clean blood from her hands, but to a man. Besides, the protagonist's mother shows her anger and disagreement with her son's dealings via the re-interpretation of the line, behaving as the protagonist's alter ego. All these instances reimagine the character of Lady Macbeth completely, who, either functions as the protagonist's conscience or turns against him, seems to be the paragon of virtue and evil is not part of her nature. The idealization of female characters on the Indian screen (women as wives, mothers and sisters) clearly affected the representation of the Shakespearean character in the $20^{\text {th }}$ century.

However, this essay argues there is a change in the depiction of Lady Macbeth in $21^{\text {st }}$ century Indian film adaptations of Macbeth, Maqbool (dir. Vishal Bhardwaj, 2003) and Veeram (dir. Jayaraj, 2016), and the female character is as evil as in the source text. But to make it work on the Indian screen, the Lady Macbeth in these $21^{\text {st }}$ century adaptations is not married to the Macbeth character (the implication being an Indian married woman is incapable of such atrocities), so that sexual drive is one of the main mottos and sexuality is related to evil. In addition, elements of the vamp -the "naughty, sexually alluring" woman (Virdi 167) that is an Indian phenomenon- are included in these Lady Macbeths. This paper aims to show that these Lady Macbeths are as based on the Shakespearean character as on the role of the vamp in popular Indian movies, since characters that are sexually driven are always condemned to death.

According to Douglas Lanier, a Shakespearean adaptation should not be conceived in a "single, privileged relation to a Shakespearean text but rather in a multiplicity of relations to an ever-changing aggregate of adaptations" (Lanier 35) and traditions. Via the discussions pursued in the sections of this article, this essay then highlights how the Lady Macbeth figure is both indebted to Shakespeare's Lady

* This article is one of the outputs of the Marie Skłodowska-Curie Fellowship entitled Indian Cinematic Traditions. Project ID 752060. Horizon 2020 Framework Programme.

${ }^{1}$ All references from Shakespeare are to the Complete Works, Ed. Stanley Wells et al., 1986. 
Macbeth and the figure of the vamp; the two traditions interact with each other in a unique combination. Maqbool and Veeram expand considerably the source text, adding female characters that were not present in Shakespeare's Macbeth. According to Margaret Jane Kidnie, the source text is not a fixed entity, but undergoes a transformation. Along these lines, Linda Hutcheon claims adaptations are creative processes (2006: XII). Both Maqbool and Veeram transform the source text via their reworking of Lady Macbeth, and via the addition of new female characters -Sameera (Duncan's daughter in Maqbool) and Unniyarcha (a woman warrior who is part of a love triangle in Veeram) which were not present in Shakespeare's play to serve as either the antithesis to the protagonist or parallel figures. Even in the female characters added to the plot, the lack of sexuality -verging on the idealization of the female character (Sameera) - is rewarded, whereas sexual assertiveness is always punished. These $21^{\text {st }}$ century Indian adaptations of Macbeth not only generate new understandings of the Shakespearean play, but also deal with controversial issues in Indian culture, such as sexuality.

\section{INDIAN LADY MACBETHS: NIMMI AND KUTTUMANI}

Vishal Bhardwaj and Jayaraj are two auteurs in Indian cinema, which "stands as a breed apart from crass commercialisms" (Burnett 55). In both cases, their cinematic venture with the Bard consists of a trilogy. Vishal Bhardwaj is the director of Maqbool (2003), Omkara (2006) and Haider (2014), based on Macbeth, Othello and Hamlet respectively. Jayaraj is the director of Kaliyattam (1997), Kannaki (2002) and Veeram (2016), modelled on Othello, Antony and Cleopatra and Macbeth. Although part of the auteur brand, Vishal Bhardwaj's Maqbool and Jayaraj's Veeram are very different reworkings of Macbeth. Maqbool is set in contemporary Mumbai, whereas Veeram is not set in contemporary Kerala, but in "ritual and folkloristic" Ellora (Venkiteswaran 81). Interestingly, the constant use of the handheld camera in Maqboolallows the spectators to see constant images of a contemporary Mumbai. The main locations in Veeram are Ellora Caves, where most of the action takes place.

The locales in the movie acquire epic proportions; they give the film a "sort of timelessness in which the protagonists acquire larger-than-life dimensions" (Venkiteswaran 91). While Maqbool revolves around the dealings of a mafia don (Abbaji/Duncan) and his cohort (Maqbool/Macbeth, Kaka/Banquo, Guddu/Fleance and Malcolm), Veeram (aka Valour) is based on folklore that are the Northern Ballads "and are part of the oral tradition in North Kerala" (Venkiteswaran 81). ${ }^{2}$ The story of Veeram focuses on Chanthu/Macbeth, who is made the chief of kalaris (warrior castes in Kerala, experts in martial arts) by Aromal Chekavar of the legendary Puthooram house. Chanthu must accompany Aromal Chekavar to a duel against his enemy Aringodar but, lured by Kuttumani (the Lady Macbeth character), manipulates the

\footnotetext{
${ }^{2}$ Northern ballads basically focus on the heroic deeds of local warriors.
} 
iron rivets of the sword with wooden ones. Despite this trick, Aromal still wins and is killed by Chanthu and Kuttumani. The 'betrayer Chanthu' (a popular figure in folklore) is finally killed by Aromal's son Aromalunni. Thus, the attitude towards the local of Maqbool and Veeram is slightly different. Veeram incorporates traditional folk culture in an attempt to take part in a regional cinema that tries to find its place within global cinema; it animates Macbeth anew as a play that supports a regionally inspired agenda. In contradistinction, Maqbool mixes the local with the global unashamedly throughout the film.

Despite the difference in the approach to the Shakespearean source, the character of Lady Macbeth in both films shares many aspects in common. Lady Macbeth in both movies is evil, and both openly plot murders. Kuttumani's speech before murdering Aromal Chekavar is very close to Lady Macbeth's in 1.5.36-52: "Oh Goddess! Let all the evil and murderous spirits enter my body and take away all my kindness and compassion. Let there be no human compassion in me that will prevent me from accomplishing my evil plan. Let my breasts swell with poison and not milk". As in the Shakespearean source, the language used suggests that her womanhood prevents her from performing violent and cruel acts. This speech is almost entirely omitted in Maqbool because the film presents a maternal Lady Macbeth. This becomes a major reworking of the Shakespearean source, clearly influenced by Kurosawa's Throne of Blood, which equally incorporated a pregnant Lady Macbeth. ${ }^{3}$ Unlike Lady Macbeth, neither Nimmi nor Kuttimani is married to Macbeth. Nimmi is Abbaji's mistress but is secretly in love with Maqbool and Kuttimani (Lady Macbeth in Veeram) is also willing to be with Chanthu.

Apart from the love they profess for Maqbool and Chanthu, their motives (unlike Lady Macbeth's) go beyond mere ambition. It is their unmarried status what locks them in a status of vulnerability and permanent suffering. While Nimmi is being replaced by Abbaji for a new mistress/lover-leaving Nimmi in a complicated status that would prevent her from going back to her family home- Kuttumani is dependent on her uncle Aringodar and, upon his death in the duel, she would be alone. Domestic distress and wellbeing and Shakespearean aspiration come together in the representation of the tensions that give rise to murder.

Maqbool and Veeram are distinctive in the ways in which they promote sexual drive during events. This represents a major reworking of the Shakespearean source, eroticizing it more. If Macbeth is mostly a tragedy about ambition, in Maqbool and Veeram sexuality and lure seem to be more important than ambition; "sexual desire is the predominant transgression in Maqbool" (Ferleman). Cinematography and language constantly contribute to that; both Nimmi and Kuttumani manipulate

${ }^{3}$ As Andrew Fleck notes (283), adaptations of Macbeth on the stage and on the screen have frequently introduced the idea that the Macbeths lost a son. Cheryl Campbell, in Adrian Noble's production, worked with Derek Jacobi's production on the idea they had lost a child. The BBC Macbeth on the Estate (1997) similarly hinted Lady Macbeth had lost a son. Even Justin Kurzel's Macbeth (2015) incorporated a scene with the Macbeths crying over their dead child. 
Maqbool and Chanthu at ease, they both make sexual advances to achieve their purposes.

In the case of Nimmi, her display of sexuality is subtle. At the outset of the movie, when Maqbool is drinking water, she claims: "Is that all you are thirsty for?" and later in the film, she states "I have twelve moles on my body. Do you want to count them all?" (00:20:39). To these verbal advances must be added visual episodes that alert us to Nimmi's manoeuvres. On the way to the temple, Nimmi is "openly manipulative" (Burnett 61) when she deliberately steps on a nail so that Maqbool is forced to help her, touch her feet, and hold her hand. The celebration (and veneration) of the feet in popular Hindi cinema generates "mystery and (male) desire" (Uberoi 117). According to Uberoi, the feet are corporeal signifiers and she calls this "podo-erotics". As the narrative unfolds, another obvious example of overt manipulation presents itself when at the summit of a hill, in a shot-reverse-shot, she grabs a gun and, at gunpoint, confronts Maqbool's love and fears and elects to choose Maqbool and turns against her patron-lover.

Similarly, in Veeram, sexual tension dominates the reworking of Shakespeare's Macbeth. But characteristic of Jayaraj's vision are the explicit erotic scenes. In a shotreverse-shot, Kuttumani becomes a sexual agent, takes off her clothes in front of Chanthu and is resolute to have sex with him. Laura Mulvey's iconic gaze theory (1975) posited a female body that was passive in its articulation of desire to satisfy the male gaze, but Kuttumani is not passive, she is rather presented as a desiring subject with a desire of her own; she aggressively pursues the man she loves. After the sexual encounter with Kuttumani, Chanthu is willing to kill Aromal Chekavar (the Duncan counterpart) to be with her. In Maqbool, it is the love for Nimmi what makes Maqbool/Macbeth kill the Duncan character. Sexuality, evil and power seem to go hand in hand.

The introduction of evil in the Lady Macbeth character in $21^{\text {st }}$ century Indian adaptations and its association with sexuality needs to be analysed in relation to the figure of the vamp, the femme fatale of popular Hindi cinema in the 1970s and 1980s. This reworking of Lady Macbeth owes as much to the Shakespearean character as to the vamp. Although definitions of the vamp vary, Gokulsing and Dissanayake (1998), Dwyer and Patel (2002), Pinto (2006), Mazumdar (2007) and Dark (2008) coincide in the fact that it is a "figure of desire, who occupied a morally ambiguous, hypersexualised space on screen" (Rekhari 134). She was depicted as the sexualized woman using eroticized gestures and movements, inviting the male gaze.

The vamp was usually involved in despicable activities, sometimes in gangs, "played the part of gangsters' and smugglers' moll" (Kishore 142) and was always framed in contrast to the heroine in a kind of wife/prostitute dyad or vamp/virgin binary. There were two opposing forces at work, a black and white conception of characters. The wife was idealized, depicted as pure and chaste, the epitome of kindness and goodness, whereas the vamp was mean, seductive, violent and promiscuous. Despite the audience's pleasure with the vamp, she was morally condemned with a very clear double-speak; the narrative invited the audience "to see and then condemn the figure of the vamp" (Virdi 169). All the films from the 1970s and 1980s with vamps (the golden age of this liminal figure) punished them 
with death, which was usually an accident of fate. From Teesri Manzil (1968) to all the movies in which Helen (the vamp par excellence) played a role, they all included "vamps" that had to pay with their death. ${ }^{4}$ Besides eroticism, an open display (and exploitation) of sexuality to manipulate others and their engagement with the villains, and even gang leaders in the case of Nimmi, Maqbool and Veeram operate like these films from the 70s and 80s and condemn the sexually voracious Nimmi and Kuttumani with their death.

Curiously enough, their fates are even more terrible than Lady Macbeth's. Nimmi dies a natural death, but, in this case, "her guilt about killing one of the possible fathers of her child" (Gil Harris 167) is what drives her to madness. After giving birth, Nimmi is not allowed to be with her own son for a single moment. In a culture that values mother-son relationships tremendously -and the film Mother India (1957) is only an instance of that- Maqbool anatomizes a maternal Lady Macbeth that is punished with the worst penance, the possibility of seeing and touching her new-born son. As Mark Burnett argues, once Nimmi becomes pregnant, she is "branded 'mother,' 'whore' and 'witch"' (63). But while the term 'mother' is only used once after the announcement of her pregnancy, the terms 'whore' and 'witch' assume more importance as the narrative unfolds.

The film fleshes out Nimmi's lack of aptitude to be a mother since the beginning of her pregnancy when Maqbool already questions the parentage, as if a desiring subject did not deserve being a mother. The episodes in which she claims her baby 'wails' inside her womb or even when the child is born "of premature labor" (Trivedi 2009) emphasize a maternal crisis. The internal logic of the Indian family is vital to understand that Maqbool wishes to question the status of the vamp as mother via the reworking of a maternal Lady Macbeth. In Veeram, Kuttumani does not die a natural death, but performs a terrible suicide with a sword. In a spectacular scene in which Kuttumani uses a handful of colours, the camera zooms into her and, in a powerful medium shot, commits a horrendous suicide with one of the swords used in the previous duel. The ambiguity of Lady Macbeth's death in the Shakespearean source is skilfully and openly resolved in Veeram. Maqbool and Veeram present alternative deaths to the character, expanding it considerably.

\section{ADDITIONAL FEMALE CHARACTERS}

Richard J. Hand distinguishes "addition" as one of the five strategies of adaptation (17). Interestingly, Maqbool and Veeram incorporate other female characters to the source text to provide a contrast to the female leads, with different consequences. Maqbool, for instance, substitutes Duncan's sons for a daughter who serves as the antithesis of Nimmi, whereas Veeram draws a parallel between the two

${ }^{4}$ Helen is an Indian film actress, who appeared in Bollywood movies of the 1970s and 80s. Her dance numbers in these films are well-known in India. 
female leads, Kuttumani (Lady Macbeth) and Unniyarcha and what the future holds for them also looks quite similar.

Maqbool imagines the Duncan counterpart (Abbaji) with a daughter (Sameera), who has a romantic relationship with Banquo's son in this adaptation (Guddu). The film narrative presents Sameera as the antithesis to Nimmi. The palette of colours used for Nimmi mainly includes crimson and red (as when she declares her love for Maqbool), whereas that for Sameera mainly comprises pastel colours. The beginning of the film draws a parallel between the two pairs of lovers (Nimmi/ Maqbool and Sameera/Guddu), which soon disappears. On the way to the shrine, "close-ups of the furtive, adoring looks exchanged between the two pairs of lovers as they worship clearly map erotic love onto mystical religious worship" (Croteau 145). While the love Nimmi feels for Maqbool is illicit and forbidden, Sameera's love for Guddu (once it is revealed by Maqbool) is well-received and Kaka and Abbaji give their consent for a wedding. Nimmi's love for Maqbool comprises lust and sexual desire, whereas Sameera's love for Guddu seems pure and innocent.

Exchange of looks, light touches of hands and gentle smiles are characteristic of Sameera and Guddu's romance. In line with the argument of the vamp/Nimmi, Sameera engages in the dichotomy that was so common in the 70s and 80s in Bollywood cinema. Although the onscreen representations of femininity are changing on the Indian screen (Gehlawat 53), Maqbool is still trapped in the past regarding its depiction of female characters. The preference for an idealised female character lacking sexual desire is clear at the end when Sameera and Guddu appear holding Nimmi and Maqbool's baby lovingly in a middle-shot. Not only does Nimmi die before seeing her own son, but she also is replaced as a mother by a more capable and suitable woman. Sexual assertiveness has terrible consequences for Nimmi.

Interestingly, Maqbool introduces a third female character that has no equivalent in Shakespeare's Macbeth, and works as a sexual rival to Nimmi. Mohini is a Bollywood actress, who replaces Nimmi as Abba-ji's lover. During the "Jhin Min Jhini" song (00:58:43-01:03:24), two different realms are combined: the female realm with all the women dancing outdoors and the male realm indoors in which an item number takes place. While Nimmi and Sameera are dancing during the wedding celebrations surrounded by women in an atmosphere of sorority, Mohini oversees an item number that takes place indoors, in front of all the men. She is portrayed as a sexualized body, dancing and trying to arouse the male gaze. With a light pink salwar kameez, abundant jewellery and numerous flowers as a kind of hair accessory, she twirls around endlessly and moves her hips. The camera zooms into certain parts of the body selectively considered sexual: her lips, eyes, cleavage, hips, and hypersexualized body movements so that she is the object of male gaze twice, for Abba-ji's acolytes as the viewers in the film and for the male audience that may be watching the film. The "Jhin Min Jhini" song finishes uniting the two realms, the female realm and that of the men.

Abba-ji approaches the couple (Sameera and Guddu) accompanied with Mohini, and even dances with her, which should be understood as a clear sign of Abba-ji's replacement of Nimmi in favour of Mohini. If elements of the vamp clearly emerge in Nimmi, Mohini is a 70s and 80s typical Bollywood vamp. According to 
Ganti, "because the vamp was always excluded from the field of domesticity, she was allowed to assert her sexuality" (190). And this is Mohini's case. But Mohini also serves as an instance of how the beginning of the illicit relationship between Abba-ji and Nimmi started, for she seems to follow on Nimmi's footsteps.

Similarly, Veeram equally expands the source text by introducing another female character, Unniyarcha. The character of Unniyarcha is a popular legendary warrior, who seems to have lived in Kerala during $16^{\text {th }}$ century. Unniyarcha is the sister of Aromal Chekavar. When Aromal is murdered by Chanthu, she decides to take revenge, and Chanthu is finally killed by Aromalunni, Unniyarcha's son. Unlike Sameera in Maqbool, she is not idealised and is not depicted as the polar opposite of Kuttumani. The film narrative introduces Unniyarcha as a sexually voracious woman. Though married, she "inflames" Chanthu's "old passion for her and urges him this time to protect the life and glory of her brother" (Venkiteswaran 90). Shot-reverseshots of the couple show their sweating torsos and their desires to be together. The main characteristic of this scene is the presence of swords. Chanthu and Unniyarcha appear holding swords during their sexual encounter, which puts them at the same level and highlights their strength and bravery as well as their roles as warriors.

The powerful middle shot of Chanthu breaking Unniyarcha's necklace, which seems to lead to the consummation of sex, is however interrupted by the footsteps of Unniyarcha's husband. Unniyarcha immediately raises from bed to prevent her husband from discovering her with Chanthu. Therefore, the sexual act between Chanthu and Unniyarcha is never consummated. The images of Unniyarcha with her husband in opposition to the shots of an abandoned Chanthu inform the audience -and remind Chanthu- of the fact that he was "denied the hand of his childhood sweetheart, Unniyarcha, in marriage" (Mukherjee 315). The events that ensue shed light on the importance of sexual lure in the adaptation, for Chanthu is erotically charged by Kuttumani, the sexual act is consummated, and he fights for her family instead of Unniyarcha's. Given that Unniyarcha is depicted as a sexually voracious woman, but unable to consummate the act with Chanthu, the film narrative emphasizes this ambiguity in the ending. Seeking revenge for her brother's death, she plots Chanthu's death on her son's hands.

One of the last scenes of the film shows a close-up of Chanthu's head as it flies in the air to end in Unniyarcha's hands, which interestingly appear full of blood, in a clear reminiscence of this character to Lady Macbeth. Although the film rewards her with Chanthu's death for having murdered her brother, it also condemns her to a future similar to Kuttumani's and Lady Macbeth's, for it seems to suggest that remorse will be part of her life. Kuttumani committed suicide because she could not forget her participation in Aromal's murder, and the ending seems to hint at an analogous fate for Unniyarcha. Sexuality is equally tied to evil in the character of Unniyarcha, and the ending suggests how this female character will also be punished. 


\section{CONCLUSION}

One of the latest Indian adaptations of Macbeth, Abhaya Simha's Paddayi (aka West, 2018) depicts Lady Macbeth as an erotic force. This Tulu adaptation of Macbeth introduces the Lady Macbeth character Sugandhi-meaning pleasant smellas a person full of sexual drive. Interestingly, Sugandhi's first conversation revolves around sex. The Macbeths are newlyweds, who enjoy their sexual life. In an explicit middle shot of the couple with their bare torsos, Sugandhi is sexually voracious. Her sexual lure increases even more when she discovers a perfume that comes from the West. Completely hypnotised by it, she steals it from Duncan's house under the nose of his wife (with special needs). As Thea Buckley notes, "if Shakespeare's Lady Macbeth moans wretchedly 'All the perfumes of Arabia will not sweeten this little hand"' (V.I. 44-45), in Simha's wrenching Tulu-language version, this fragrance is materialized early on, its exotic scent representing escape from poverty, banality, and mortality" (8). Like in Maqbool, the Lady Macbeth in Paddayi gets pregnant in the course of the film but differs from Maqbool in that she has a miscarriage at the place where everything started -Duncan's house- and in front of his disabled wife. This film, like Maqbool, emphasizes how a woman who is sexually assertive does not deserve to be a mother on the Indian screen, and sexuality is punished again.

Although, as Jyotika Virdi argues (167), the figure of the vamp disappeared as such by the 1980 s, elements of this figure have been incorporated into these new Lady Macbeths (Nimmi and Kuttumani). A differently conceived Lady Macbeth is an effect of the films's adaptive choices in relation to the play to highlight sexuality is still a controversial issue on the Indian screen. Despite the fact Maqbool and Veeram may come across as radical Indian Shakespeares in their conception of overt sexuality, they remain an integral part of Indian cinema in the end. By bringing to the forefront the complex negotiations between Shakespeare, Indian culture and Indian cinema aesthetics, Maqbool and Veeram give new nuances to the Shakespearean character, but further complicate the role of the Indian woman as sexual agent on the Indian screen, still emphasizing there is no room for eroticism on the Indian screen, unless it is finally condemned. If the films with the figure of the vamp lapsed in the 1980s, this revival suggests how systems of representation in Indian cinemas are characterized by circularity.

The Shakespearean character needs to fit the demands of Indian audiences and culture and, for that reason, needs to be reworked. Following Robert Stam's terminology, Maqbool and Veeram would be transformations of the source text since both films expand and cut the narrative at the same time. They "generate other texts in an endless process of recycling, transformation, and transmutation, with no clear point of origin" (66). Linda Hutcheon equally emphasizes how film adaptations create "something new" (20). Maqbool and Veeram create a new text, which can be seen in the figure of Lady Macbeth, which is reworked at length. The films force us to reconceive the meaning of Shakespeare. 


\section{WORKS CITED}

Agneepath. Dir. Mukul Anand. Dharma Productions. India, 1990.

Burnetr, Mark. Shakespeare and World Cinema. Cambridge University Press, 2013.

Buckley, Thea. "The Tulu Paddayi [Macbeth]: Sea of Blood.” Paper presented at Performance and Adaptations of Macbeth. SAA, 2020.

Croteau, Melissa. “Bollywood Macbeth, Othello." Shakespeare and Emotion. Ed Katharine A. Clark. CUP, 2020. 136-150.

Dark, J. "Crossing the Pale: Representations of White Western Women in Indian Film and Media." Transforming Cultures e-Journal 3/1 (2008): 124-144.

Dwyer, Rachel and Divya Patel. Cinema India: The Visual Culture of Hindi Film. Rutgers University Press, 2002.

Ferleman, William C. "What if Lady Macbeth Were Pregnant?: Amativeness, Procreation, and Future Dynasty in Maqbool." Asian Shakespeares on Screen: Two Films in Perspective. Ed. Alexander C.Y. Huang. Borrowers and Lenders: The Journal of Shakespeare and Appropriation 4/2 (2009): np.

FLECK, Andrew. "A Barren Sceptre" (3.1.63): Generation, Generations and Destiny in Maqbool and Global Adaptations of Macbeth." Shakespeare on Screen: Macbeth. Ed. Victoria Bladen, Sarah Hatchuel \& Nathalie Vienne-Guerrin. Presses Universitaires of Rouen and le Havre, 2014. 281-300.

Ganti, Tejaswini. Bollywood: A Guidebook to Popular Indian Cinema. Routledge, 2004.

Gehlawat, Ajay. Twenty-first century Bollywood. Routledge, 2015.

Gil Harris, Jonathan. Masala Shakespeare. Aleph, 2018.

Gokulsing, K. Moti and Wimal Dissanayake. Indian Popular Cinema: A Narrative of Cultural Change. Trentham Books, 2004.

Jwala. Dir. Vinayak. India, 1938.

Haider. Dir. Vishal Bhardwaj. Vishal Bhardwaj Pictures. India, 2014.

Hand, Richard J. "Victor Hugo's Lucretia Borgia and Adaptation." Redefining Adaptation Studies. Ed. Dennis Cutchins, Laurence Raw, James M. Welsh. Lanham. The Scarecrow Press, 2010. 17-30.

Kaliyattam. Dir. Jayaraj Rajasekharan Nair. 2016.

Kannaki. Dir. Jayaraj Rajasekharan Nair. 2016.

Kidnie, Margaret Jane. Shakespeare and the Problem of Adaptation. Routledge, 2009.

Kishore, Vikrant. "Bollywood Vamps and Vixens: Representations of the Negative Women Characters in Bollywood Films." Transgressive Womanhood: Investigating Vamps, Witches, Whores, Serial Killers and Monsters. Ed. Manon Hedenborg-White \& Bridget Sandhoff. Brill, 2014. 139-151.

LANIER, Douglas. "Shakespearean Rhizomatics: Adaptation, Ethics, Value." Shakespeare and the Ethics of Appropriation. Ed. Alexa Huang \& Elizabeth Rivlin. Palgrave, 2014. 21-40.

Maqbool. Dir. Vishal Bhardwaj. Kaleidoscope Entertainment, 2003.

Mazumdar, R. Bombay Cinema: An Archive of the City. University of Minnesota Press, 2007. 
Mother India. Dir. Mehboob Khan. Mehboob Productions. India, 1957.

Mukherjee, Sangeeta. Innovations in Language, Culture and Communication. Evincepub Publishing, 2020.

Mulvey, Laura. "Visual Pleasure and Narrative Cinema." Screen 16/3 (1975): 6-18.

Omkara. Dir. Vishal Bhardwaj. Eros International Entertainment, 2006.

Paddayi. Dir. Abhaya Simha. 2018.

Pinto, Jerry. Helen: The Life and Times of an H Bomb. Penguin, 2006.

Rekhari, Suneti. "Sugar and Spice: The Golden Age of the Hindi Movie Vamps, 1960s-1970s." Bollywood and Its Other(s): Towards New Configurations. Ed. Vikrant Kishore, Amit Sarwal \& Parichay Patra. Palgrave Macmillan, 2014.

Shakespeare, William. Complete Works. Ed. Stanley Wells et al. Clarendon Press, 1986.

Stam, Robert. "Beyond Fidelity: The Dialogics of Adaptation." Film Adaptation. Ed. James Naremore. Athlone, 2000. 54-76.

Teesri Manzil. Dir. Vijay Anand. Nasir Hussain Films, United Producers. India, 1966.

The Stage of Blood. Dir. Lokendra Arambam. India, 1997 [Performance].

Throne of Blood. Dir. Akira Kurosawa. Kurosawa Production Company, 1957.

Trivedi, Poonam. "It Is the Bloody Business Which Informs Thus...: Local Politics and Performative Praxis, Macbeth in India." World-wide Shakespeares: Local Appropriations in Film and Performance. Ed. Sonia Massai. Routledge, 2005. 47-57.

Trivedi, Poonam. "Filmi’ Shakespeare," Literature/Film Quarterly 35/2 (2007): 148-58.

Trivedi, Poonam. "Mak[ing]... Strange/ Even to the Disposition that I Owe': Vishal Bhardwaj's Maqbool." Asian Shakespeares on Screen: Two Films in Perspective. Ed. Alexander C.Y. Huang. Borrowers and Lenders: The Journal of Shakespeare and Appropriation 4/2 (2009) online: http://www.borrowers.uga.edu/.

Uberoi, Patricia. Freedom and Destiny: Gender, Family and Popular Culture in India. Oxford University Press, 2006.

Veeram. Dir. Jayaraj Rajasekharan Nair. 2016.

Venkiteswaran, C.S. "Shakespeare in Malayalam Cinema: Cultural and Mythic Interface, Narrative Negotiations." Shakespeare and Indian Cinemas: Local Habitations. Ed. Poonam Trivedi \& Paromita Chakravarti. Routledge, 2018. 75-92.

VIRDI, Jyotika. The Cinematic ImagiNation: Indian Popular Films as Social History. Rutgers University Press, 2003. 
